\title{
Brain imaging abnormalities in CNS virus infections
}

Supplemental data at www.neurology.org
Unlike bacterial and fungal meningitis in which imaging abnormalities are not specific for a particular agent, many virus infections of the CNS produce MRI abnormalities not seen by any other infectious agent. The changes caused by the specific virus can also be produced by noninfectious disorders. Imaging changes must always be evaluated in conjunction with the clinical symptoms, signs, and laboratory abnormalities, particularly the presence of a CSF pleocytosis. The purpose of this montage is to ensure that the clinician includes the specific virus in the differential diagnosis (figure).

Donald H. Gilden, MD, Denver, CO

Disclosure: The author reports no conflicts of interest.

Address correspondence and reprint requests to Dr. Donald H. Gilden, Department of Neurology, Mail Stop B182, University of Colorado Health Sciences Center, 4200 East9th Ave., Denver, CO 80262; don.gilden@uchsc.edu.

References are available on the Neurology ${ }^{\mathbb{B}}$ Web site at www.neurology.org.

\section{Figure Brain imaging abnormalities in CNS virus infections}
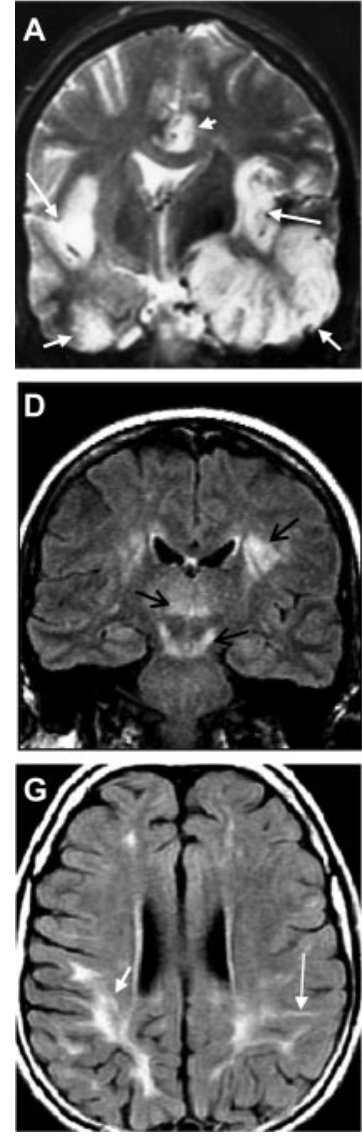
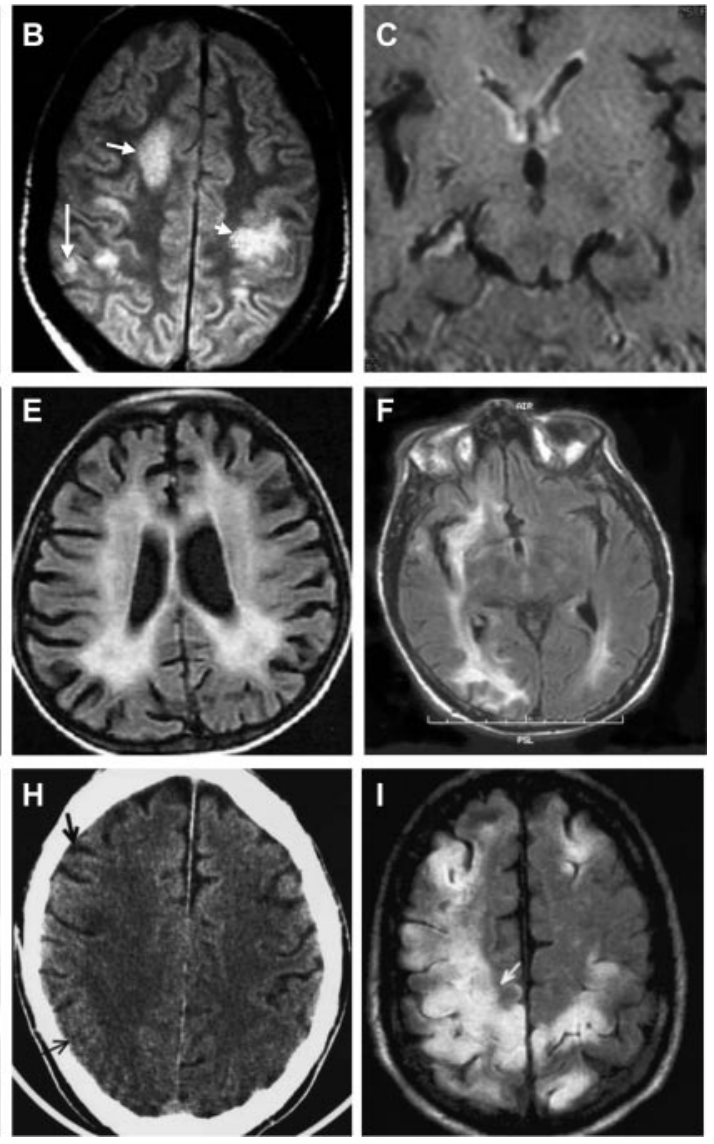
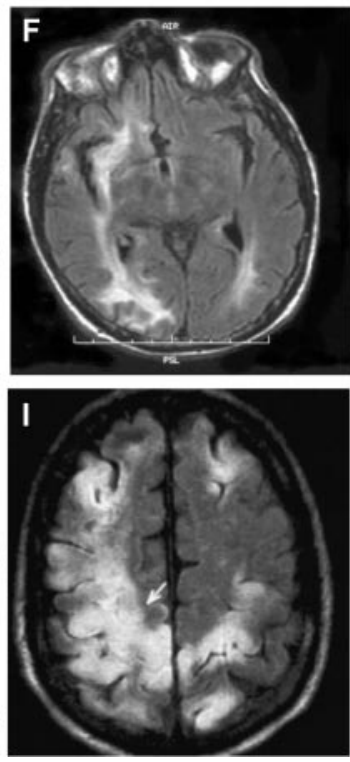

(A) Herpes simplex virus encephalitis. Abnormal signal and edema in the left temporal lobe (short bottom arrow), insula (long arrow) and cingulate gyrus (arrowhead), sparing deep nuclear structures with mass effect compressing the left lateral ventricle and uncal herniation; also not increased signal in the right inferomedial temporal lobe (short bottom arrow) and insular cortex (long arrow). Differential diagnosis includes glioma and Rasmussen encephalitis (both usually restricted to one hemisphere), abscess, granuloma, limbic encephalitis, and paraneoplastic disease; the latter two disorders would not produce the mass effect seen here. (B) Varicella zoster virus vasculopathy. Ischemia/infarction more common in white matter (top arrow), particularly at gray-white matter junctions (short arrow), less frequently in gray matter (long arrow) and may enhance. Differential diagnosis includes metastatic carcinoma, embolism/endocarditis and CNS vasculitis, although vasculitic lesions are usually smaller and do not have a predilection for gray-white matter junctions. (C) Cytomegalovirus encephalitis. Characteristic enhancement in ependyma around lateral ventricles. Differential diagnosis includes varicella zoster virus ependymitis, abscess rupture, meningitis, shunts, chemotherapy, and subependymal spread of various brain tumors (glioma, pinealoma, lymphoma). (D) Togavirus encephalitis. Deep-seated structures characteristically involved: subcortical white matter (top arrow), thalami (middle arrow), and substantia nigra (bottom arrow). In this case, the lesions were caused by West Nile virus; the same areas are disproportionately infected by other togaviruses (St. Louis encephalitis virus, Japanese encephalitis virus, and Eastern and Western equine encephalitis viruses) and occasionally in Creutzfeldt-Jakob disease. (E) HIV infection of the CNS. Characteristic abnormalities are brain atrophy and diffuse white matter attenuation. Differential diagnosis includes long-standing hypertension, chemotherapy, or X-irradiation; in the latter three conditions, the extent of the white matter abnormalities usually exceeds the degree of brain atrophy. (F) JC virus infection of the CNS causes progressive multifocal leukoencephalopathy. Typical multifocal and confluent subcortical nonenhancing white matter hyperintensities extending to the cortical gray matter. Differential diagnosis includes CNS lymphoma, glioma, disseminated encephalomyelitis, sarcoidosis exclusively in white matter, chemotherapy, and X-irradiation. (G) Acute disseminated or postinfectious encephalomyelitis after virus infection. Subcortical white matter lesions (short arrow) involving subcortical U fibers with tangential lesions (long arrow). Differential diagnosis includes disorders listed in F. Brain imaging is frequently normal in viral encephalitis. Occasionally, nonspecific changes consist of either sulcal effacement (H) (thin arrow), compared with normal sulcal spaces (thick arrow); or increased signal (I) (arrow), reflecting increased water content in the mildly swollen brain of the same patient. These changes developed in a patient with probable enterovirus encephalitis but can be produced by many viruses, as well as after head injury and in various metabolic encephalopathies. 


\title{
Neurology
}

\author{
Brain imaging abnormalities in CNS virus infections \\ Donald H. Gilden \\ Neurology 2008;70;84 \\ DOI 10.1212/01.wnl.0000286937.09760.e4
}

This information is current as of December 31, 2007

\section{Updated Information \& Services \\ Supplementary Material \\ Subspecialty Collections}

Permissions \& Licensing

Reprints including high resolution figures, can be found at: http://n.neurology.org/content/70/1/84.full

Supplementary material can be found at: http://n.neurology.org/content/suppl/2007/12/28/70.1.84.DC1

This article, along with others on similar topics, appears in the following collection(s):

Acute disseminated encephalomyelitis

http://n.neurology.org/cgi/collection/acute_disseminated_encephalomy elitis

All Imaging

http://n.neurology.org/cgi/collection/all_imaging

Encephalitis

http://n.neurology.org/cgi/collection/encephalitis

Viral infections

http://n.neurology.org/cgi/collection/viral_infections

Information about reproducing this article in parts (figures,tables) or in its entirety can be found online at:

http://www.neurology.org/about/about_the_journal\#permissions

Information about ordering reprints can be found online:

http://n.neurology.org/subscribers/advertise

Neurology ${ }^{\circledR}$ is the official journal of the American Academy of Neurology. Published continuously since 1951, it is now a weekly with 48 issues per year. Copyright . All rights reserved. Print ISSN: 0028-3878. Online ISSN: 1526-632X.

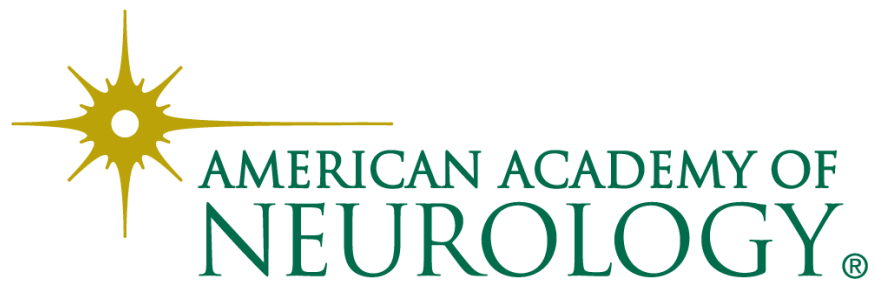

